\title{
Dental enamel ultrastructure in Ochotona and Prolagus (Mammalia: Lagomorpha: Ochotonidae) from three late Miocene localities in Ukraine
}

\author{
Emilia Rabiniak, Leonid Rekovets, and Dariusz Nowakowski
}

\begin{abstract}
The comparison of the dental enamel of late Miocene ochotonids from the Ukraine shows only very subtle differences. The ultrastructure of premolars, molars, and incisors of pikas: Ochotona and Prolagus (Lagomorpha, Ochotonidae) from three localities (Popovo 3, MN 11; Verkhnya Krynytsya 2, MN 12; Lobkove, MN 12/13) is mainly multilayered. In cheek teeth it is composed of a radial (up to $60 \%$ of total enamel thickness) and an irregular layer (up to $40 \%$ ). There is almost no difference in the enamel ultrastructure between remains of different geological age and tooth position (premolars, molars). However, the lower incisor of Ochotona differs from the upper one in having a radial enamel and a HSB layer, whereas the upper have a radial and a tangential enamel. Minor differences between the various species of Ochotona and Prolagus could be recognised in the arrangement of the prisms.
\end{abstract}

Emilia Rabiniak. Wroclaw University of Environmental and Life Sciences, Department of Biology and Animal Breeding, 51-630, Wroclaw, Chelmonskiego 38c, Poland. emilia.rabiniak@up.wroc.pl Leonid Rekovets. Wroclaw University of Environmental and Life Sciences, Department of Biology and Animal Breeding, 51-630, Wroclaw, Chelmonskiego 38c, Poland. leonid.rekovets@up.wroc.pl Dariusz Nowakowski (corresponding author). Department of Anthropology, Institute of Biology, Wrocław University of Environmental and Life Sciences, ul. Kożuchowska 5, 51-631 Wrocław, Poland. darekn@hot.pl

Keywords: Lagomorpha; tooth; enamel; ultrastructure; Miocene

Submission: 25 July 2015 Acceptance: 4 September 2017

Rabiniak, Emilia, Rekovets, Leonid, and Nowakowski, Dariusz. 2017. Dental enamel ultrastructure in Ochotona and Prolagus (Mammalia: Lagomorpha: Ochotonidae) from three late Miocene localities in Ukraine. Palaeontologia Electronica 20.3.46A: 1-12 palaeo-electronica.org/content/2017/1998-enamel-ochotona-and-prolagus

Copyright: September 2017 Palaeontology Association.

This is an open access article distributed under the terms of Attribution-NonCommercial-ShareAlike 4.0 International (CC BY-NC-SA 4.0 ), which permits users to copy and redistribute the material in any medium or format, provided it is not used for commercial purposes and the original author and source are credited, with indications if any changes are made. creativecommons.org/licenses/by-nc-sa/4.0/creativecommons.org/licenses/by-nc-sa/4.0/ 


\section{INTRODUCTION}

The evolution of dental morphology of European ochotonids (pikas) is relatively well known due to many publications (e.g., Tobien, 1963; López-Martínez, 1974; Tobien, 1974, 1975; Agadjanian and Erbajeva, 1983; Erbaeva, 1988; LópezMartínez, 1989, 2001; Tesakov and Averianov, 2002; López-Martínez, 2008; Angelone and Sesé, 2009; Čermák, 2010; Fostowicz-Frelik, 2010; Fostowicz-Frelik et al., 2010; Angelone and Čermák, 2014; Lissovsky, 2014). However, only few papers deal with the enamel ultrastructure of this family. von Koenigswald and Martin (1984) have published a series of works on various aspects of morphology, evolution, and function of enamel layers in various Lagomorpha of different geological age (von Koenigswald and Clemens, 1992;von Koenigswald, 1996; Martin, 1999, 2004; von Koenigswald et al., 2010). However, the enamel microstructure of ochotonids from sites of south-eastern Europe has not been studied in detail. The region is relatively well explored and plays an important role in the history of faunal exchanges between Asia and Europe, and in the formation of the extant species ranges. Studies on the enamel ultrastructure of Neogene and Pleistocene small mammals of this region have so far dealt with Castoridae only (Rekovets and Nowakowski, 2013). Ontogenetic changes of enamel have been investigated in some late Neogene species of Spalax (Rekovets et al., 2014).

This work provides new data on the enamel microstructure of incisors, premolars and molars of several Late Miocene taxa of Prolagus and Ochotona (Ochotonidae) from Ukraine in order to complement the current knowledge.

\section{MATERIAL AND METHODS}

The material included the third lower premolars (p3), molars, and incisors from the Upper Miocene Ukrainian localities Popovo 3 (MN 11, Upper Sarmatian), Verkhnya Krynytsya 2 (MN 12, Upper Meotian), and Lobkove (MN 12/13). The general information on the sites, and on the qualitative and quantitative composition of their fauna can be found in Rekovets and Pashkov (2009); Čermák and Rekovets (2010); Rekovets et al. (2014). All three sites hold alluvial deposits of the Dnieper River containing gravels and sands, and remains of small mammals (Table 1). The faunas indicate a dry climate with the prevalence of steppes. The food of herbivores consisted of tough plants which should be reflected in the morphology of the teeth.

Samples of the following taxa were included in the analysis: Prolagus aff. crusafonti and Ochotona sp. from Popovo 3, Ochotona cf. eximia from Verkhnya Krynytsya 2, and Ochotona sp. from Lobkove. We cannot definitely exclude that all the Ochotona specimens under consideration actually belong to the same species. However, in any case the teeth are of different age. The preparation of teeth for the analysis followed von Koenigswald (1980), and improved in later works. The method was slightly modified by omitting the cut with a diamond saw (IsoMet ${ }^{\circledR}$ Low Speed Saw), which can cause teeth damage; the specimens were ground

TABLE 1. A list of specimens including species of lagomorphs, types of teeth, numbers of images, and excavation locations/age.

\begin{tabular}{|c|c|c|c|c|}
\hline No. & Taxon & Tooth position & Locality age & $\begin{array}{c}\text { No. of microscope } \\
\text { images }\end{array}$ \\
\hline 1. & Ochotona cf. eximia & p3 & $\begin{array}{c}\text { Lobkove } \\
\text { MN } 12 / 13 \\
\text { (Upper Maeotian,Cherevychnian stage) }\end{array}$ & $9041-9046$ \\
\hline 2. & Ochotona cf. eximia & $\begin{array}{c}\text { p3 } \\
\text { m3 } \\
\text { lower incisors }\end{array}$ & $\begin{array}{c}\text { Verchnia Krynica } 2 \\
\text { MN } 12 \\
\text { (Lower Maeotian, Belkian stage) }\end{array}$ & $\begin{array}{l}9026-9037 \\
9843 \\
9812\end{array}$ \\
\hline 3. & $\begin{array}{c}\text { Ochotona sp. } \\
\text { (ex.gr. kalfense) }\end{array}$ & $\begin{array}{c}\mathrm{p} 3 \\
\mathrm{~m} 2 \\
\text { upper incisors }\end{array}$ & $\begin{array}{c}\text { Popovo } 3 \\
\text { MN } 11 \\
\text { (Upper Sarmatian, Beryslavian stage) }\end{array}$ & $\begin{array}{l}0248-0261 \\
9836 \\
9768\end{array}$ \\
\hline 4. & Prolagus aff. crusafoni & $\begin{array}{l}\text { p3 } \\
\text { m3 }\end{array}$ & $\begin{array}{c}\text { Popovo } 3 \\
\text { MN } 11 \\
\text { (Upper Sarmatian, Beryslavian stage) }\end{array}$ & $\begin{array}{c}8995-9006 \\
9817-9820\end{array}$ \\
\hline
\end{tabular}

The following abbreviations were used, according to Koenigswald et al. (2010): EDJ - enamel dentine junction, HSB - Hunter-Schreger bands, IPM - interprismatic matrix, IRRE - irregular enamel (here: IR), OES - outer enamel surface, PLEX - prismless external layer, $\mathrm{R}$ - radial enamel, $\mathrm{T}$ - tangential enamel. 
immediately after embedding them in epoxy resin (Epoxy Embedding Medium kit - 45359 SigmaAldrich $\mathrm{GmbH}$ ). The quality of grinding was controlled under stereomicroscope. The samples were rinsed for 10 seconds in a $5 \% \mathrm{HCl}$ solution followed by ethanol, and placed for 30 seconds in the ultrasonic apparatus to remove the dust. The cross sections were standard for all samples and were analysed in a scanning electron microscope (Zeiss EVO LS 15) in the Laboratory of Electron Microscopy, Faculty of Biology and Animal Sciences, Wrocław University of Environmental and Life Sciences. Longitudinal sections were also made for Ochotona sp. from Popovo 3.

The lower p3s were subject to the most detailed examination, since they are the most diagnostic and functional teeth. Incisors were examined only in Ochotona. In Popovo 3 also Prolagus occurred, but it was impossible to distinguish between the incisors of the two genera. The number of examined tooth areas depended on the regions of interest and the quality of grinding. Approximately 10-12 images per tooth were taken, which was sufficient for the analysis. As a rule, the detailed photographs of enamel were taken in corresponding tooth areas (anteroconid, metaconid, hypoconid, protoconid). The nomenclature of tooth elements follows Čermák (2009) and von Koenigswald et al. (2010). The images were taken at different magnifications (approximately 1000times). Preparation, grinding, and photographing were carried out in the Department of Ecology and Vertebrate Palaeontology, University of Environmental, and Life Sciences in Wrocław.

The stratigraphic subdivision for the Eastern Paratethys, used in this paper, follows Topachevski et al. (1998) and Nesin and Nadachowski (2001).

\section{Enamel Ultrastructure of Lagomorph Teeth}

The tooth enamel is made of specific prisms, which resemble elongated crystals (hydroxyapatite crystallites) and are connected by IPM matrix. The prisms may vary in their arrangement, shape, length, and structure, but also in the relative inclination to each other. The lagomorph enamel was initially divided into three basic types which were adopted from von Koenigswald's (1980) description of rodent enamel. Later, von Koenigswald and others (von Koenigswald, 1996; Martin, 2004; von Koenigswald et al., 2010) applied some descriptive terms in the analysis of lagomorph enamel. However, the difference is that lamellar enamel occurs only in rodents, whereas in lagomorphs this pattern is included in irregular and HSB types. According to von Koenigswald and Sander (1997) and our research, the basic enamel layer types in lagomorphs are:

1) radial type - prisms directed radially away from the EDJ; in transverse section, the prisms are perpendicular to the EDJ; in vertical section, the prisms display inclination angles from zero to nearly $90^{\circ}$;

2) tangential type - prisms have a strong lateral deviation and almost no inclination; all prisms are parallel to each other but the IPM anastomoses are nearly orthogonal; this layer occurs in lagomorphs only in incisors;

3) irregular type - irregular decussation of individual prisms or bundles of prisms; the descriptive term "irregular enamel" defines types of different evolutionary origin; in placentals, most of the irregular enamel has evolved from HSB; in marsupials, irregular enamel is derived from a radial type;

4) HSB - specific mode of prism decussation in layers, also called bands; layer bifurcations are always present; each set of layers bifurcates in only one direction; transitional zones may occur between bands;

5) PLEX - unstructured, thin layer next to the OES border.

\section{RESULTS}

\section{Prolagus aff. crusafonti from Popovo 3 (MN 11) (Figures 1, 2)}

The lower p3 enamel consists of a radial and an irregular layer. The boundary between them is easily visible and relatively distinct. The morphology of the enamel layers is similar to the situation in Prolagus oeningensis (von Koenigswald, 1996, figure 17) and Prolagus sardus (von Koenigswald and Clemens, 1992, figure 22). In all three species the two layers occur with almost $50 \%$ of the total thickness of the tooth enamel. Only in the area of the entoconid and the posterior part of anteroconid an irregular layer is present with up to $30 \%$ of the thickness; in its structure it is similar to PLEX (Figure $1, N$. 9003). The irregular layer prisms slightly interweave almost in the entire tooth (except for a thinner enamel on the ento- and hypoconid). A similar structure was observed in Prolagus sardus (von Koenigswald and Clemens, 1992, figure 22) and Prolagus oeningensis (von Koenigswald, 1996, figure 17). The arrangement of the irregular layer prisms is tangential-like, but the tangential layer prisms are arranged mostly at particular angle to each other and to the vertical axis of the tooth. In Prolagus the arrangement of the prisms is quite chaotic (Figure 1, N. 9003, 9006). 

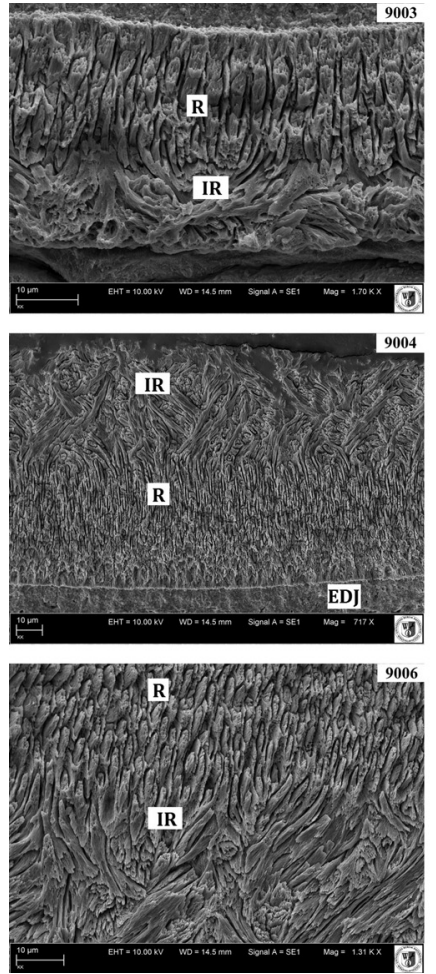

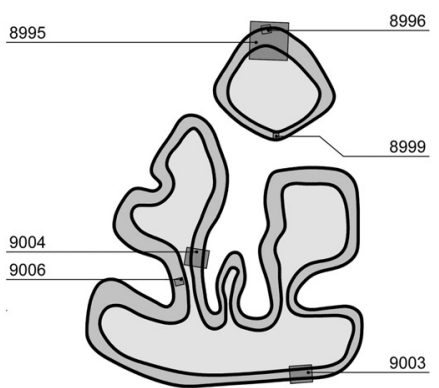

西
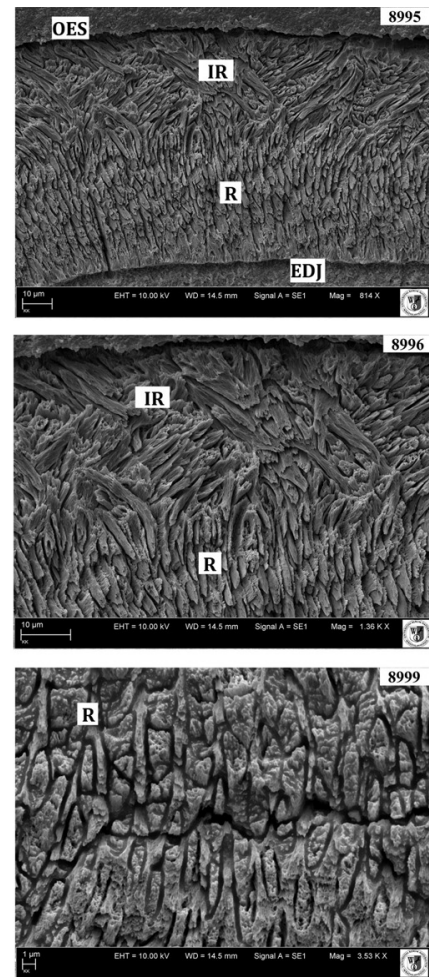

FIGURE 1. Lower $\mathrm{p} 3$ enamel ultrastructure; Prolagus aff. crusafonti from Popovo 3, cross-section.

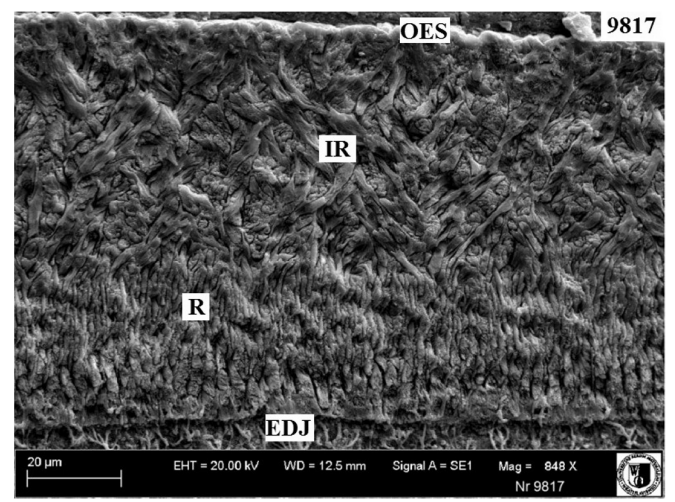

1

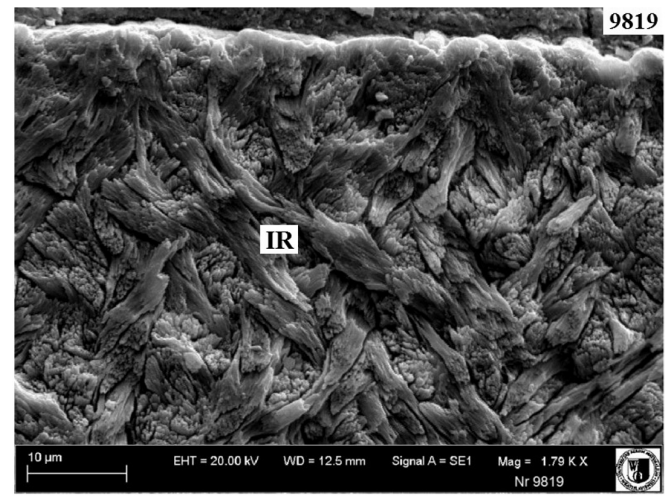

3

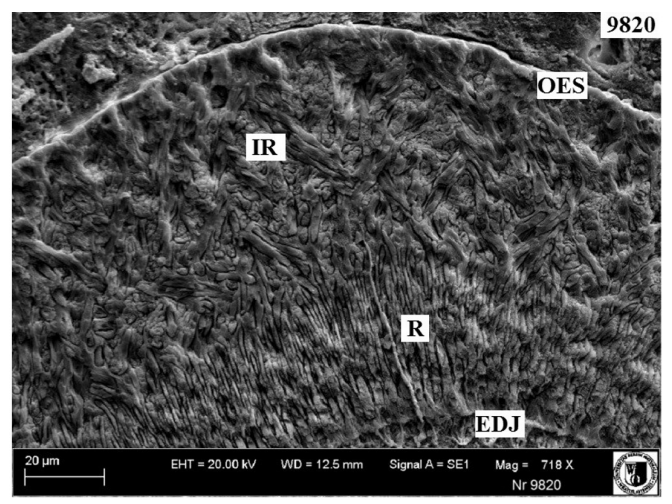

2

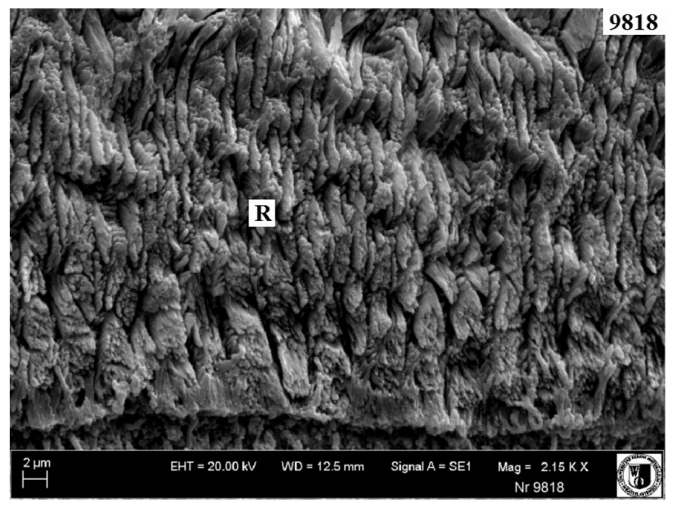

4

FIGURE 2. Posterior lobe of lower $\mathrm{m} 2$ enamel ultrastructure; Prolagus aff. crusafonti from Popovo 3 , cross- section. 14, Enamel structure details from four different tooth parts. 
The prisms of the radial layer are densely packed, gathered in tightly arranged bundles with surrounding IPM matrix (Figure 1, N. 8999, 9003, 9006). The structure of the radial layer is constant throughout the tooth; the prism bundles are arranged in parallel linear structures and slightly inclined towards the EDJ border (Figure 1, N. 8995). However, there is variation in the thickness of the radial layer, which is thinnest inside the enamel folds (Figure 1). The linear arrangement of the radial layer prisms is also characteristic of the lower molars of the two compared Prolagus species.

The enamel of the posterior lobe of the lower $\mathrm{m} 2$ of this species (Figure 2.1-4) consists also of two layers with a similar morphology to that of the p3. The only exception is that the posterior parts of the enamel bands on the posterolophid and anterolophid (after Čermák, 2009) show $70 \%$ of enamel prisms of the irregular type, which is dominated by vertically arranged prisms, as in the radial layer. Also the radial layer prisms are grouped more chaotically compared to the situation in p3 and do not form distinct linear bands (Figure 2). Presumably, these peculiarities of radial enamel arrangements are species-specific within the genus. The enamel in Prolagus oeningensis (vonKoenigswald, 1996, figure 17) is quite similar. Particularly the structure of the irregular layer is very similar in all compared taxa, with the exception of Prolagus aff. crusafonti, where it is narrower and more chaotically arranged (not linearly as in Prolagus oeningensis). Next to the OES border a very thin layer of the unstructured PLEX type occurs (Figure 2.1-4).

\section{Ochotona sp. from Popovo 3 (MN 11) (Figures 3-6)}

As in Prolagus, the enamel of the p3 is composed of two layers: a radial layer next to the EDJ border and an irregular layer next to the OES border. Parallel vertical prisms occur in the radial layer and somewhat intertwined prisms in the irregular layer. The width of these two layers is - in cross section of the tooth - almost equal, as it is in Prolagus. However, the irregular layer is much thinner in the recessed parts of the tooth (up to $20 \%$ of the thickness). It is also thinner in the protoconid and the metaconid - mesoflexid areas (Figure 3, N. 0250). The interweaving of the prisms of the irregular layer is more structured in comparison to Prolagus. The bands of this layer are arranged irregularly and at different angles to each other (Figure $3, \mathrm{~N} .0248$ ). The arrangement of the prisms in the radial layer in Ochotona sp. differs from that in Prolagus of similar geological age. In Ochotona, the prisms are not gathered in bundles like in Prolagus, but form a single structure on the IPM matrix and are sharpened. In cross section, they are arranged linearly and in the vertical distribution they are inclined to each other (the inclination is directed to the OES and EDJ borders) (Figure 3, N. 0259, 0260). A non-structured layer of the enamel type PLEX can be observed in the entoconid area next to the OES border (Figure 3, N. 0261).

The enamel of the lower $\mathrm{m} 2$ (Figure 4) has also two layers - a radial (almost $60-70 \%$ of the total width of the enamel) and an irregular layer (almost $30-40 \%$ of the width). The irregular layer prisms are inclined to the side and at an angle to the IPM. Next to the OES border, not very clearly visible, we assume the presence of a PLEX layer. The prisms of the radial layer are arranged almost in the same way as in the posterior lobe of the lower $\mathrm{m} 2$ of Prolagus, but more irregularly. The IPM matrix is faintly visible.

The enamel of the upper incisor (Figure 5) of Ochotona sp. has also two layers - a radial and a tangential one. The radial layer next to the EDJ border is made of vertical and inclined prisms, arranged chaotically (Martin, 1997). The tangential layer consists of slightly intertwined prisms, and occurs often also in the middle of the radial layer. A similar situation was reported by von Koenigswald (1996, figure 2) for Ochotona.

The longitudinal section of the lower incisor (Figures 6.1-2) shows a very well-developed HSB layer with a distinct IPM matrix and a radial layer with weak single prisms (not bundles). HSB structures are clearly visible. Such an arrangement of the HSB layers distinguishes this form from the less structured enamel of Prolagus oeningensis (von Koenigswald, 1996, figure 3).

\section{Ochotona cf. eximia from Verkhnya Krynytsya 2 (MN 12) (Figures 7-9)}

The enamel of the lower $\mathrm{p} 3$ is also double-layered; the irregular layer covers usually less than $50 \%$ of the enamel thickness, and the radial layer more than $50 \%$. The prisms of the radial layer are arranged in bundles of linear structure (as in Prolagus and in the $\mathrm{m} 2$ of Ochotona from Popovo 3) (Figure 7, N. 9026, 9032). The irregular layer has a different structure from Ochotona sp.- Popovo 3 , because it has virtually no prisms running vertically (more like tangential layer) and all of them are inclined towards the OES (one row) and EDJ (the row next to it) (Figure 7, N. 9027, 

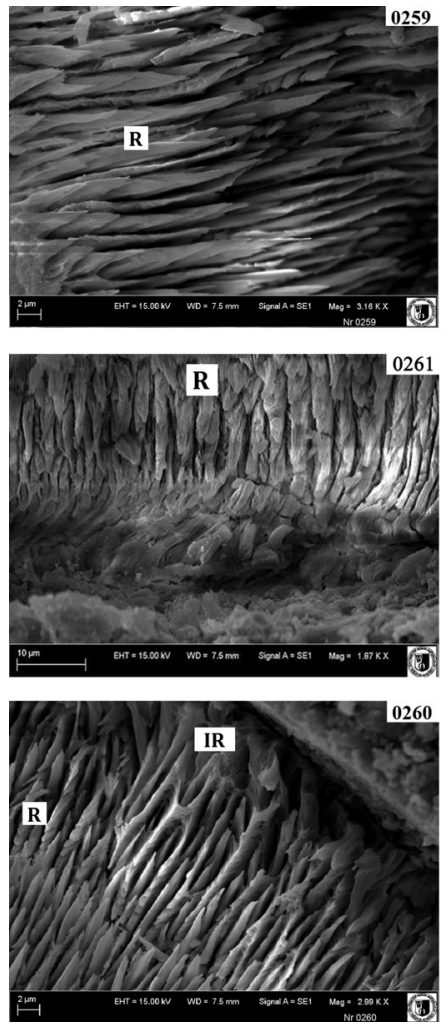
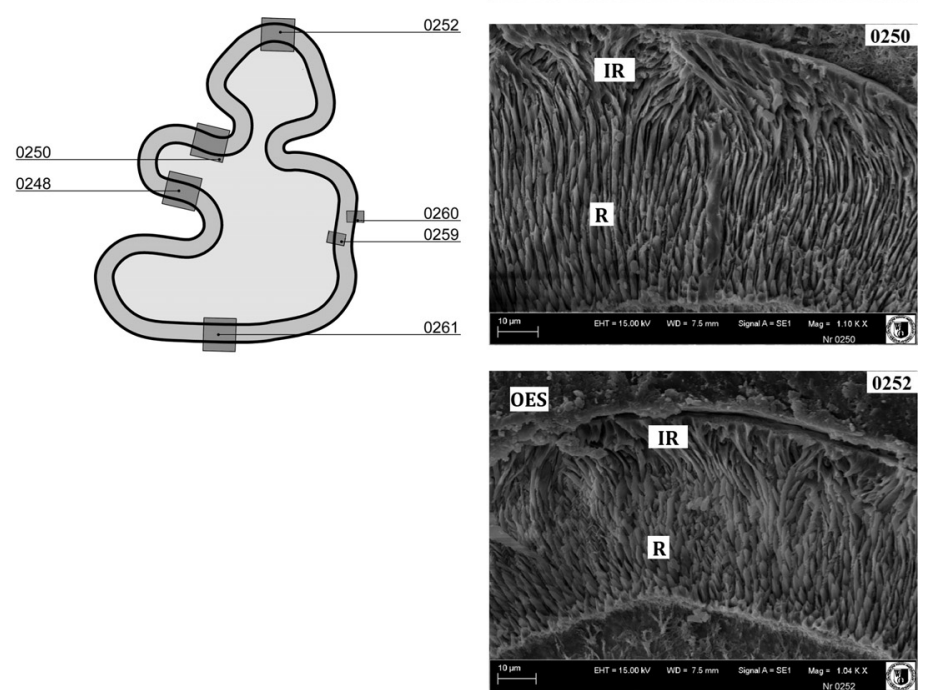

FIGURE 3. Lower p3 enamel ultrastructure; Ochotona sp. from Popovo 3, cross-section.

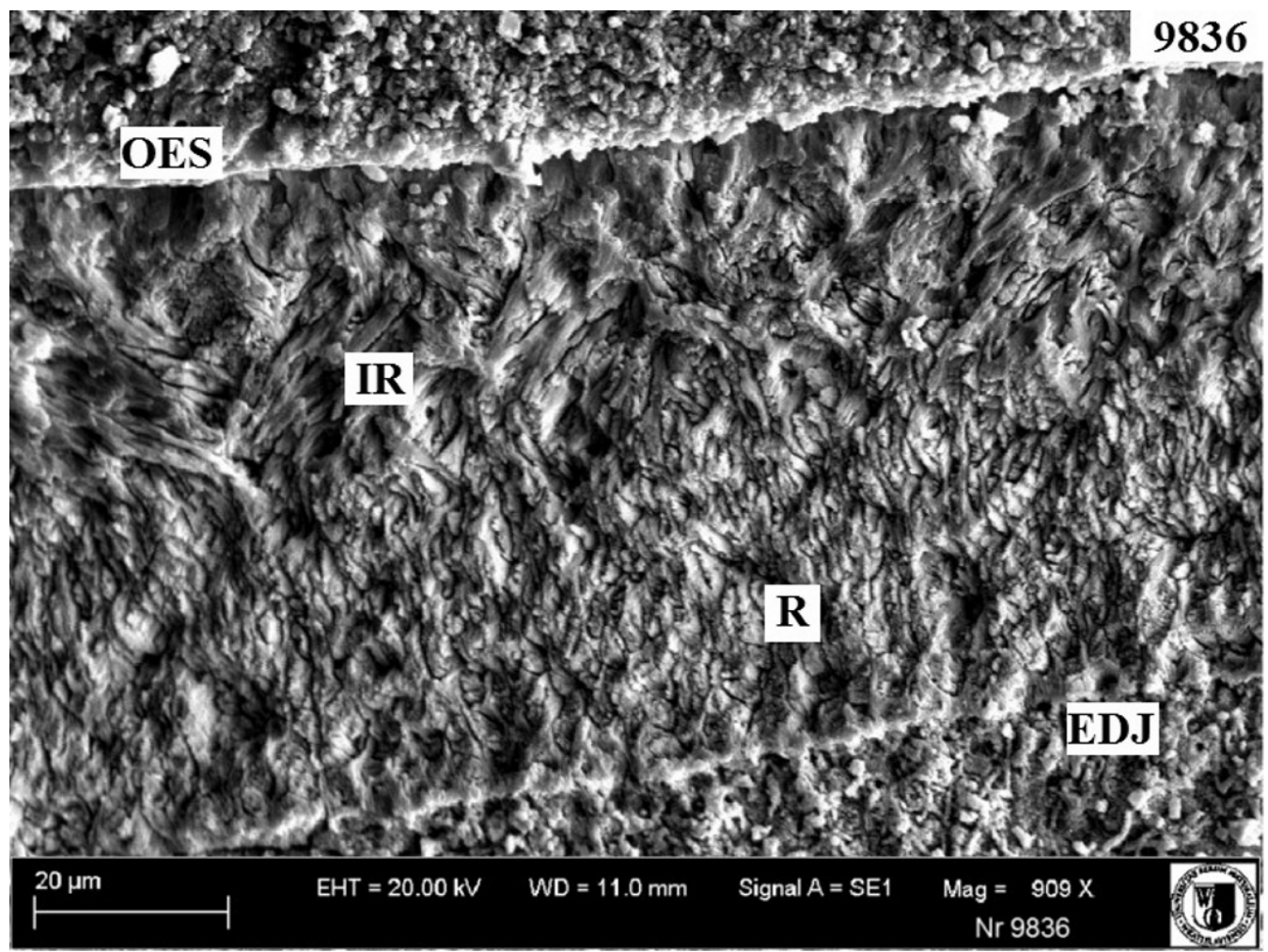

FIGURE 4. Lower m2 enamel ultrastructure; Ochotona sp. from Popovo 3, cross-section. 


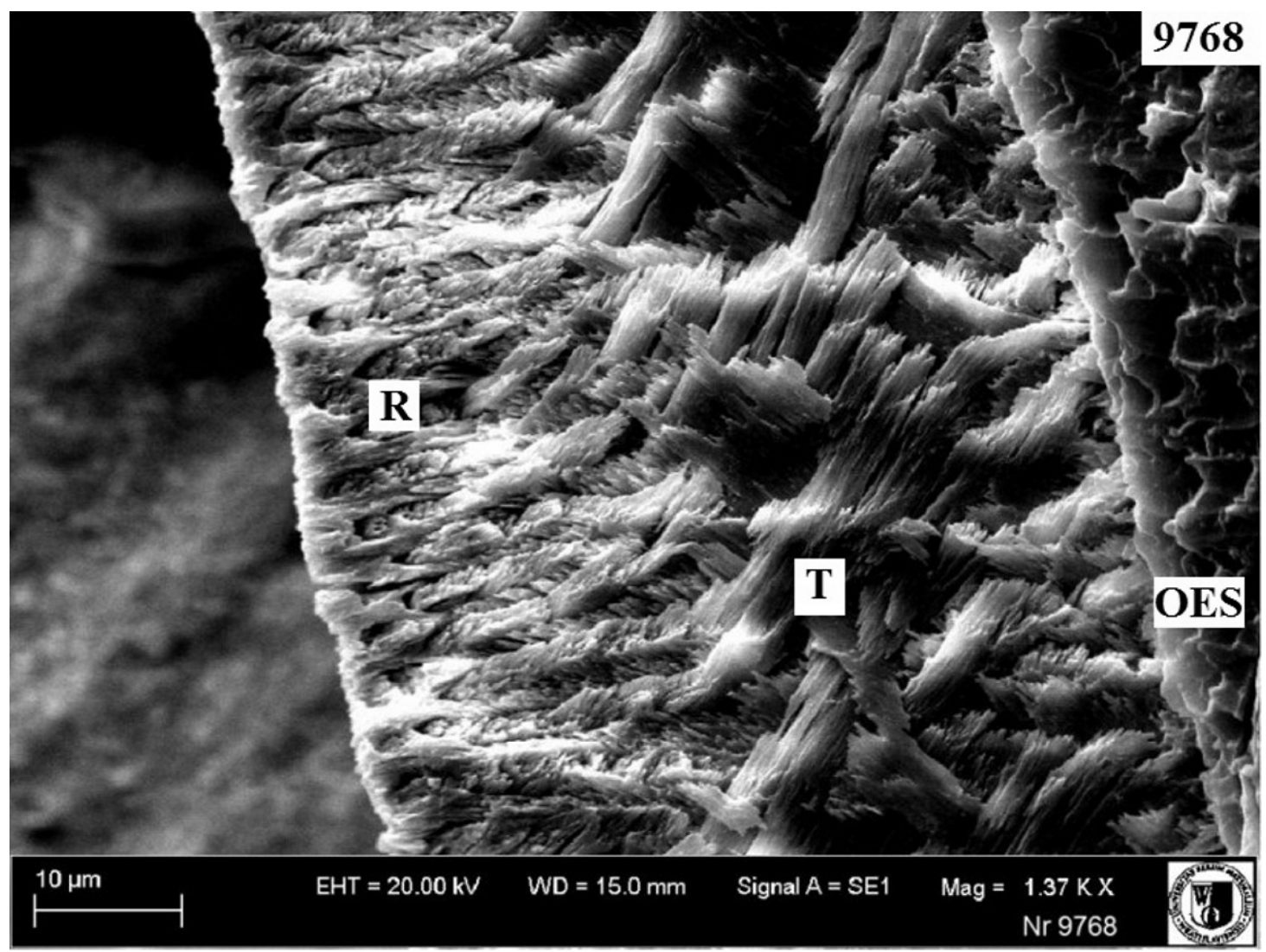

FIGURE 5. Upper incisor enamel ultrastructure; Ochotona sp. from Popovo 3 , cross-section.

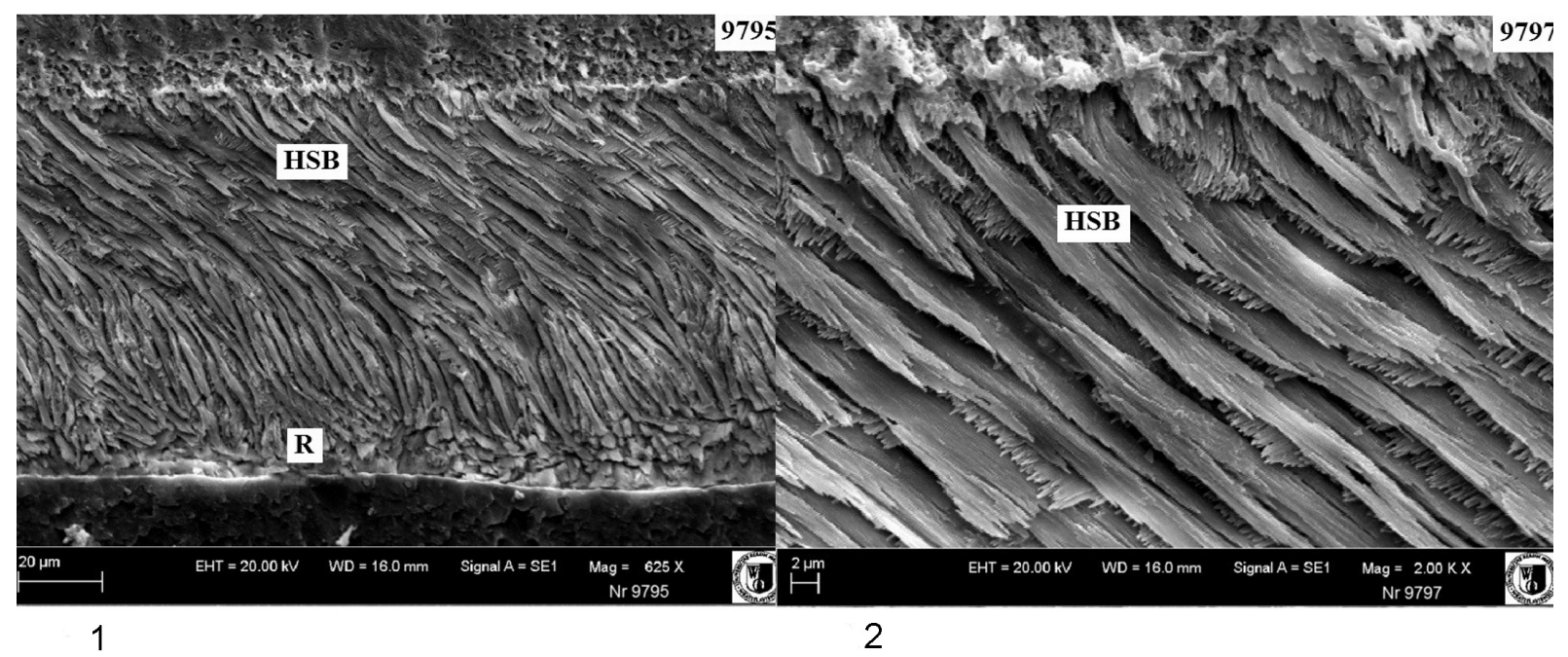

FIGURE 6. Lower incisor enamel ultrastructure; Ochotona sp. from Popovo 3, longitudinal section. 1-2, Enamel structure details from two different tooth parts. 

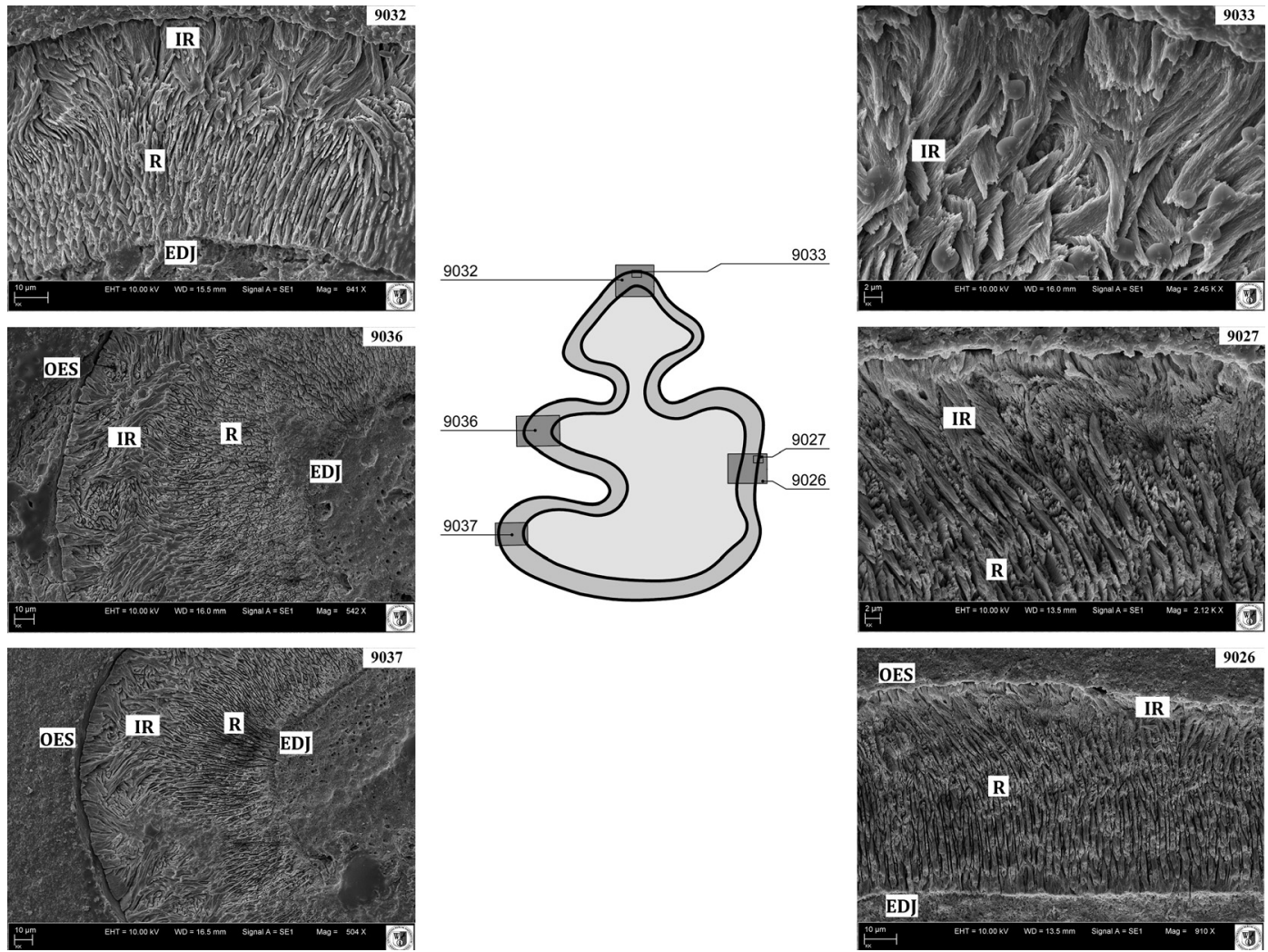

FIGURE 7. Lower p3 enamel ultrastructure; Ochotona cf. eximia from Verkhnya Krynytsya 2, cross-section.

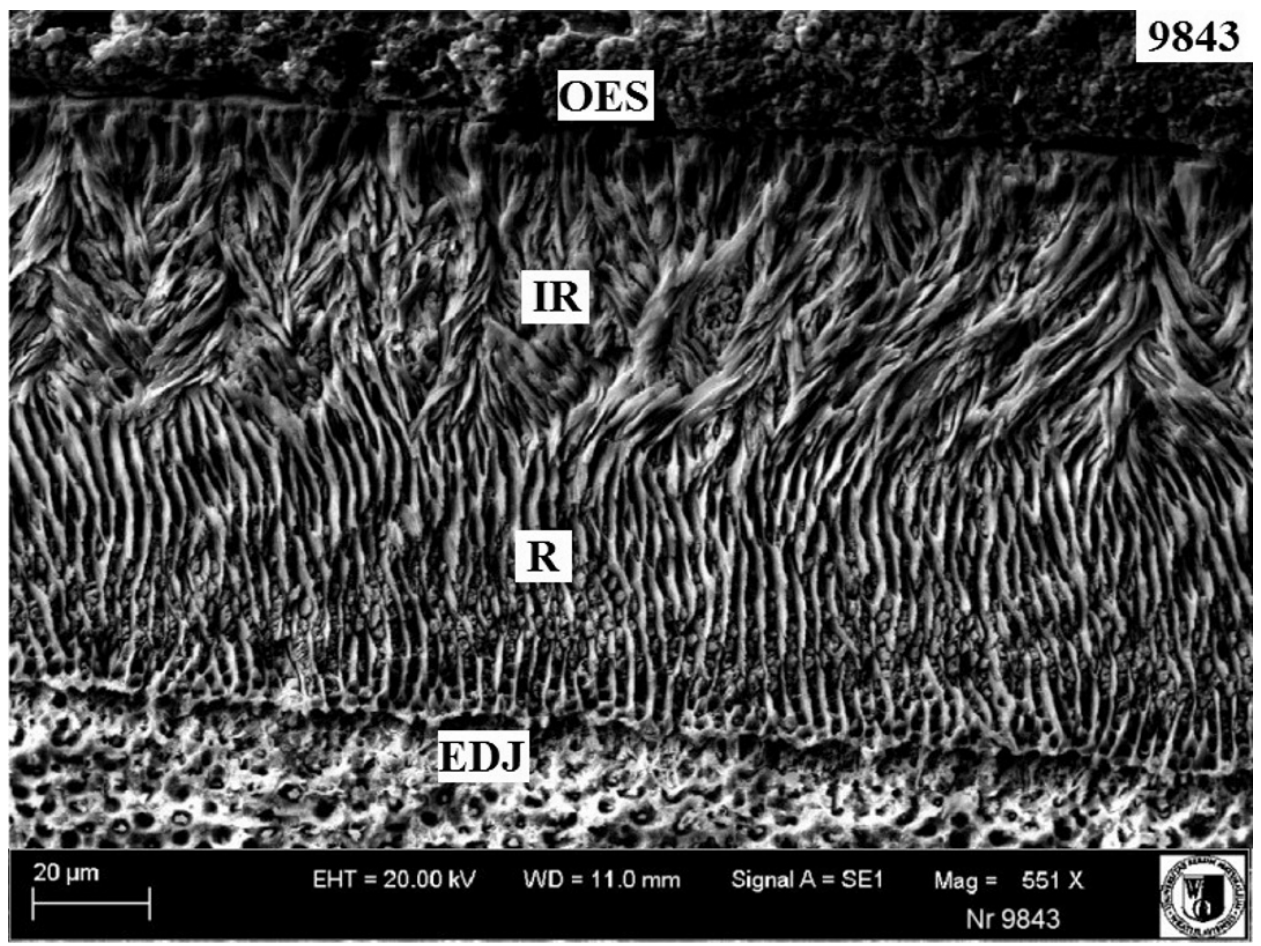

FIGURE 8. Posterior lobe of lower m2 enamel ultrastructure; Ochotona cf. eximia from Verkhnya Krynytsya 2, cross-section. 


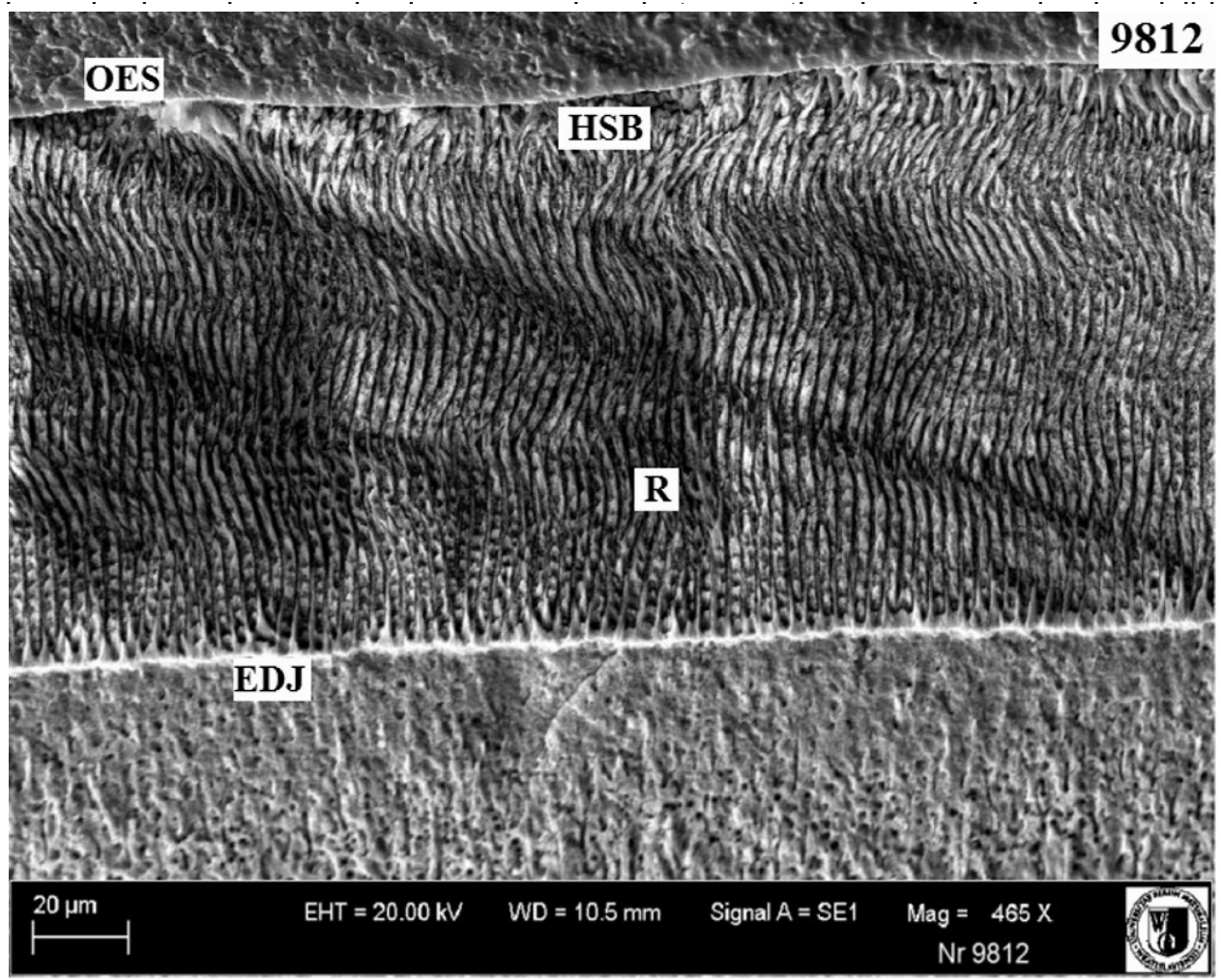

FIGURE 9. Lower incisor enamel ultrastructure of Ochotona cf. eximia from Verkhnya Krynytsya 2, cross-section.

The enamel of the p3 of Ochotona sp. from Lobkove is very similar to that of Ochotona cf. eximia. It has two layers, and the thickness of the irregular enamel is smaller than the thickness of the radial enamel. The irregular enamel has a typical structure (Figure 10, N. 9041, 9043), and the radial enamel prisms are gathered in bundles (Figure $10, N .9042$ ). Next to the EDJ border a thin layer of an indeterminate structure is sometimes visible (possibly PLEX) (Figure 10, N. 9046). Interestingly, the enamel on the base of the entoconid area is thin and consists mainly of a radial layer and an amorphous-prismatic structure, which has not been observed so far in other teeth (Figure 10, N. 9045).

\section{DISCUSSION}

In Prolagus and Ochotona from the Late Miocene localities of Ukraine the lower p3 enamel is composed of two layers - an outer one, consisting of irregular enamel next to the OES border and an inner one consisting of radial enamel next to EDJ. In almost all sections of the p3 enamel, the two-layered structure can be recognised, with the dominance of the radial layer occupying more than $50 \%$ of the total enamel thickness. The boundary kove) the irregular layer is variable, and is more primitive and not decussate on the meta- and entoconid (Figure 7, N. 9027, Figure 10, N. 9046). The variation of the enamel thickness on $\mathrm{p} 3$ has been explained in other studies as an indicator of functional pressure on its different parts. Based on our data and literature information, it can be concluded that enamel with a thick and more structured irregular layer experiences the greatest functional pressure of the tooth. This concerns primarily the anteroconids and the outer conids of the p3. Additionally, in Prolagus and Ochotona the irregular enamel in p3 is almost identically structured. In Ochotona sp. from Lobkove, this type of enamel has vertical and inclined piles, which may resemble the tangential enamel. The radial enamel is different in grouping in bundles, which are arranged in parallel bands directed to the EDJ border. This concerns Prolagus and Ochotona, but not Ochotona sp. from Popovo 3, where similar bundles were found only on the metaconid and entoconid. In contrast to Prolagus sardus, $P$. aff. crusafonti has a less structured irregular layer. The boundary between the layers is hardly visible, the radial layer piles are more distinctly gathered in bundles, but they are less distinctly arranged in parallel bands 

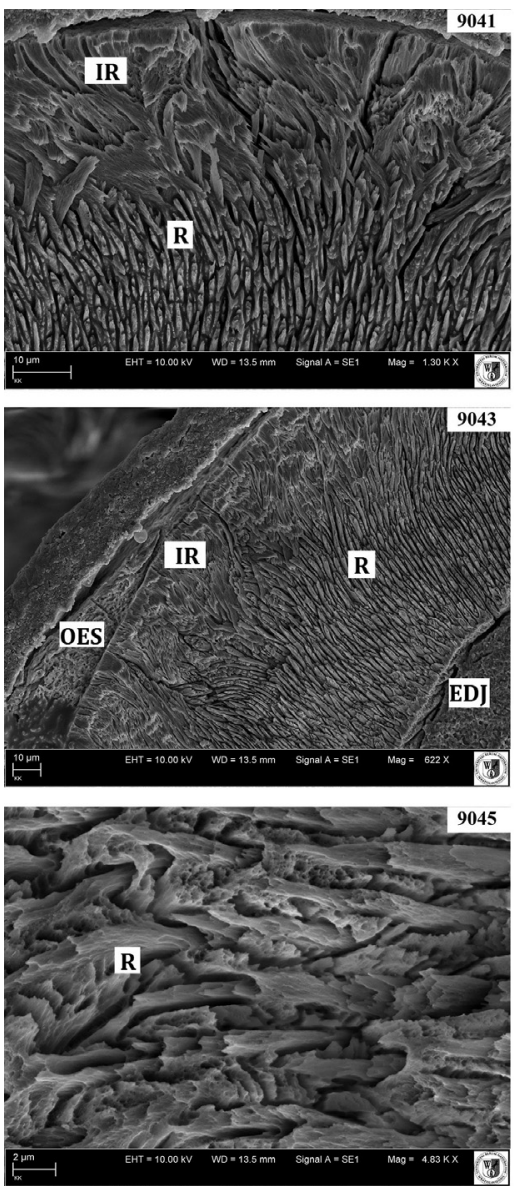
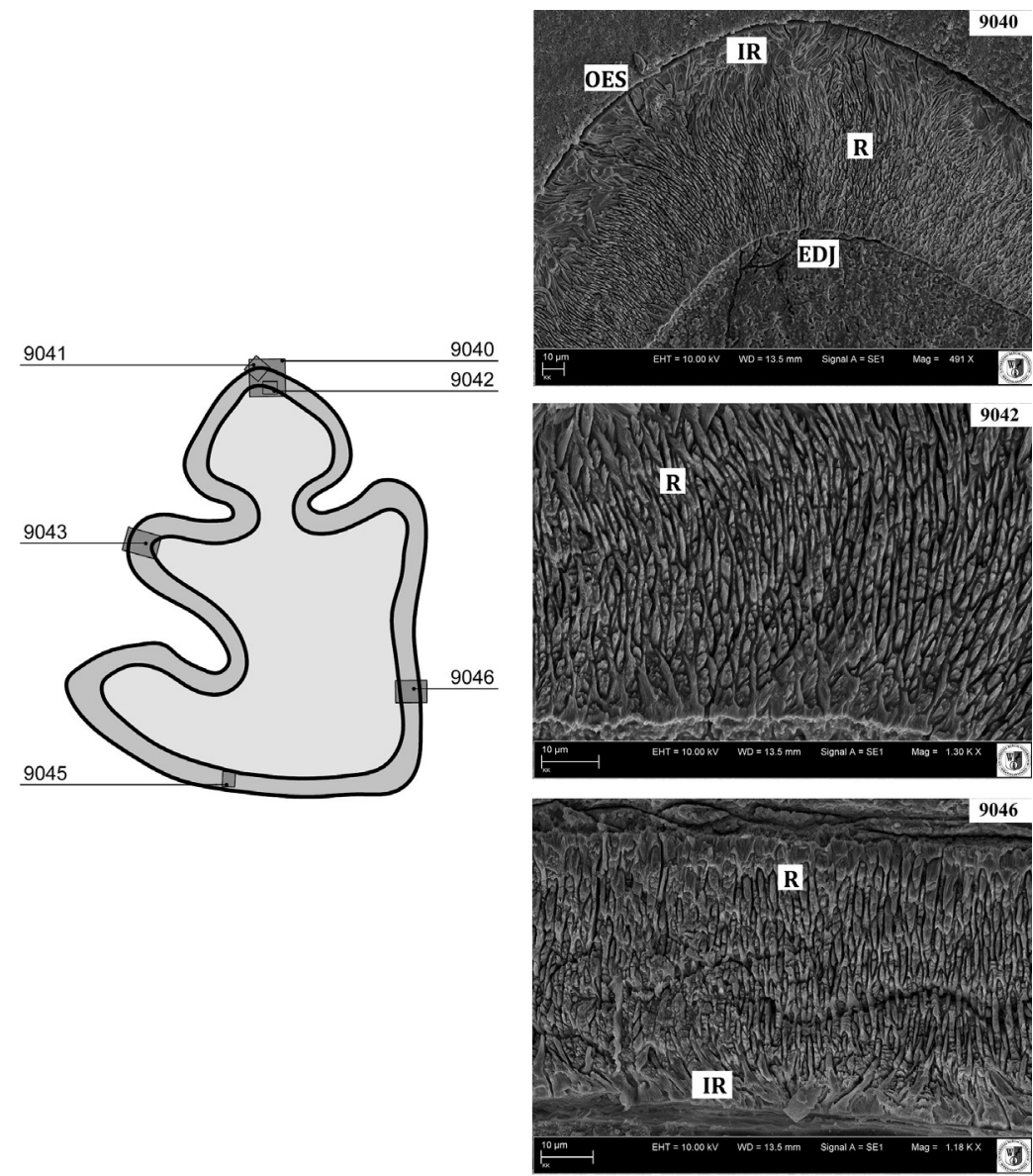

FIGURE 10. Lower p3 enamel ultrastructure; Ochotona sp. from Lobkove, cross- section.

towards the EDJ border (Koenigswald and Clemens, 1992).

The enamel of the lower molars of Prolagus and Ochotona is similar to that of the p3. The only difference is that the radial and irregular layers have a more amorphous structure, caused by the arrangement of the prisms (Figures 2, 4). In contrast to the $\mathrm{p} 3$, the bundles of piles do not form parallel linear bands directed to the EDJ border. Particularly this structure is attributed to the radial layer of Ochotona and Prolagus sp. from Popovo 3. However, in Ochotona cf. eximia these enamel layers, especially the radial type, are more structured (Figure 8). Prolagus aff. crusafonti from Popovo 3 (Figure 2) has a more primitive (amorphous) piles arrangement of the radial and irregular enamel than $P$. oeningensis: not very clear radial layer pile bands and a hardly visible boundary between the layers (von Koenigswald, 1996, figure 17). The enamel as a whole is more primitive in Prolagus aff. crusafonti in comparison to $P$. oeningensis and $P$. sardus.
Also the incisor enamel of Ochotona is made of two layers - the radial and HSB type in the lower (Figures 6, 9), and the radial and tangential type in the upper incisors (Figure 5). This enamel structure has been described in detail for Ochotona by von Koenigswald (1996, figure 1, 2, 5). The enamel structure of the upper incisors of Ochotona from the Late Miocene of Ukraine is very similar to those of the extant Ochotona princeps (Martin, 1999, figure 7A) and of O. pusilla (von Koenigswald, 1996, figure 5). One difference is that the tangential enamel in the extant Ochotona pusilla is located directly next to the OES border, while in the recent $O$. princeps and $O$. sp. from the Miocene of Popovo 3 it occurs in the middle of the radial layer. The radial enamel in O. pusilla consists of prisms gathered in structured bundles, in contrast to the situation in fossil Ochotona, where this structure is more amorphous (Figure 5). However, the lower incisors described by us (Figures 6, 9) have radial and HSB layers, which are very similar to those described by von Koenigswald (1996) and Martin (1999). The enamel of the lower incisor is also 
rather similar in the extant 0 . princeps (Martin, 1999, figure 7D). However, in O. cf. eximia from Verkhnya Krynytsya 2 the radial layer prisms are collected in bundles and arranged in linear parallel structures (Figure 9) whereas in O. princeps they are arranged in round-shaped IPM matrix.

Based on this investigation, we can conclude that the enamel ultrastructure of all the studied teeth of the late Miocene Prolagus and Ochotona are double-layered, consisting of a primitive irregular type and a radial type. Basically, the two-layer structure of the enamel is also specific for the extant Ochotona species (von Koenigswald et al., 2010).

\section{CONCLUSIONS}

Summarizing, we can conclude that:

1 - The dental enamel ultrastructure of late Miocene ochotonids from the Ukraine shows only very subtle differences. The enamel of both premolars and molars of Ochotona and Prolagus is basically composed of two layers, a radial and an irregular one. The only difference between the two genera is a slight difference in the arrangement of prisms. The prisms in the radial layers are arranged in bundles except for Ochotona sp. from Popovo 3, where they occur as single elements. The irregular layer is composed of intertwined structures (prisms and IPM matrix).

2 - In Ochotona sp. m2 from Popovo 3, the radial and irregular enamel layers are more amorphous, which may be (but not necessarily) related to the great geological age of the finds (MN 11).

3 - The extension of the two enamel differs within the various dental elements (flexids and conids, i.e., particularly in anteroconid, metaconid, and entoconid), as it has been shown in several p3s.

4 - No differences in the enamel layers have been observed between teeth of Ochotona from various late Miocene (MN 11-13) Ukrainian sites.

5 - Vertical and horizontal cross sections of Ochotona incisors are in accordance with data of Ochotona from the literature, showing radial and tangential enamel in the upper, and radial and HSB in the lower incisors. This is probably associated with the different functional load on the two pairs of incisors.

6 - Since the observed differences between cheek teeth of Ochotona of an age interval of almost 12 million years (MN 11 - Holocene) are very subtle, we assume that enamel ultrastructure may be taxonomically useful only to distinguish between larger taxonomic units (above genus level) within the family Ochotonidae. In order to check this, additional research on the enamel ultrastructure of Pliocene ochotonid taxa from SE Europe like Pliolagomys, Ochotonoides will be required.

\section{REFERENCES}

Agadjanian, A. and Erbajeva, M. 1983. Late Cenozoic rodents and lagomorphs of the USSR. Nauka, 1983:1-189.

Angelone, C. and Čermák, S. 2014. Two new species of Prolagus (Lagomorpha, Mammalia) from the Late Miocene of Hungary: taxonomy, biochronology, and palaeobiogeography. Paläontologische Zeitschrift, 89:1023-1038.

Angelone, C. and Sesé, C. 2009. New characters for species discrimination within the genus Prolagus (Ochotonidae, Lagomorpha, Mammalia). Journal of Paleontology, 83:80-88.

Čermák, S. 2009. Lagomorpha (Mammalia) of the Pliocene and Pleistocene of Europe: $A$ revision of selected taxa. Unpublished Ph.D. thesis, Charles University, Prague.

Čermák, S. 2010. The Late Miocene and Pliocene Ochotoninae (Lagomorpha, Mammalia) of Europethe present state of knowledge, p. 9-28. In Nowakowski, D. (ed.), Morphology and Systematics of Fossil Vertebrates. DN Publisher, Wrocław, Poland.

Čermák, S. and Rekovets, L.I. 2010. Early Pliocene ochotonids (Mammalia, Lagomorpha) from Southern Ukraine. Geodiversitas, 32:107-120.

Erbaeva, M. 1988. Pishchukhi kainozoya (taksonomiya, sistematika, filogeniya) (Cenozoic Pikas (Taxonomy, Systematics, and Phylogeny). Nauka, Moscow.

Fostowicz-Frelik, Ł. 2010. A new species of Pliocene Prolagus (Lagomorpha: Ochotonidae) from Poland is the northernmost record of the genus. Journal of Vertebrate Paleontology, 30:609-612.

Fostowicz-Frelik, L., Frelik, G.J., and Gasparik, M. 2010. Morphological phylogeny of pikas (Lagomorpha: Ochotona), with a description of a new species from the Pliocene/Pleistocene transition of Hungary. Proceedings of the Academy of Natural Sciences of Philadelphia, 159:97-118.

Lissovsky, A.A. 2014. Taxonomic revision of pikas Ochotona (Lagomorpha, Mammalia) at the species level. Mammalia, 78:199-216.

López Martínez, N. 1974. Taux taxonomique d'évolution dans l'ordre des Lagomorphes (Mammalia). Bulletin de la Société Géologique de France, 16:422-430.

López Martínez, N. 1989. Revision sistematica y biostratigrafica de los lagomorphos (Mammalia) del neogeno y cuaternario de España. Memorias del Museo Paleontológico de la Universidad de Zaragoza, Diputación General de Aragón, 1-350.

López Martínez, N. 2001. Paleobiogeographical history of Prolagus, an European ochotonid (Lagomorpha). Lynx (Praha), 32:215-231.

López Martínez, N. 2008. The lagomorph fossil record and the origin of the European rabbit, p. 27-46. In Alves, P.C., Ferrand, N., and Hackländer, K. (eds.), 
Lagomorph Biology, Evolution, Ecology, and Conservation. Springer-Verlag Berlin Heidelberg.

Martin, T. 1997. Incisor enamel microstructure and systematics in rodents, p. 163-175. In Koenigswald, W.v. and Sander, M. (eds.), Tooth enamel microstructure. Balkema, Rotterdam.

Martin, T. 1999. Phylogenetic implications of Glires (Eurymylidae, Mimotonidae, Rodentia, Lagomorpha) incisor enamel microstructure. Mitteilungen aus dem Museum für Naturkunde in Berlin, Zoologische Reihe, 75:257-273.

Martin, T. 2004. Evolution of incisor enamel microstructure in Lagomorpha. Journal of Vertebrate Paleontology, 24:411-426.

Nesin, V.A. and Nadachowski, A. 2001. Late Miocene and Pliocene small mammal faunas (Insectivora, Lagomorpha, Rodentia) of Southeastern Europe. Acta Zoologica Cracoviensia, 44:107-135.

Rekovets, L.I., Kovalchuk, O.M., and Dema, L.P. 2014. Geology and late Neogene fauna of the Verkhnya Krynytsya 2 locality on the south of Ukraine. Evolution of organic world and stages of geological development of Earth, 111-113.

Rekovets, L. and Nowakowski, D. 2013. ZahnschmelzUltrastrukturen an Backenzahnen verschiedener Vertreter der Familie Castoridae (Rodentia, Mammalia) aus der Ukraine. Säugetierkundliche Informationen, 9:159-163.

Rekovets, L. and Pashkov, A. 2009. New localities of small Late Neogene mammals in Ukraine. Proceedings of the IGS of the NAS of Ukraine, 354-360.

Tesakov, A. and Averianov, A. 2002. Prolagus (Lagomorpha, Prolagidae) from the Pliocene of Moldova and Ukraine. Paleontological Journal, 36:85-91.

Tobien, H. 1963. Zur Gebiß-Entwicklung tertiärer Lagomorphen (Mamm.) Europas. Notizblatt des Hessischen Landesamtes für Bodenforschung zu Wiesbaden, 91:16-35.

Tobien, H. 1974. Zur Gebißstruktur, Systematik und Evolution der Genera Amphilagus und Titanomys (Lago- morpha, Mammalia) aus einigen Vorkommen im jüngeren Tertiär Mittel-und Westeuropas3. Mainzer geowissenschaftliche Mitteilungen, 3:95-214.

Tobien, H. 1975. Zur Gebißstruktur, Systematik und Evolution der Genera Piezodus, Prolagus und Ptychoprolagus (Lagomorpha, Mammalia) aus einigen Vorkommen im jüngeren Tertiär Mittel-und Westeuropas. Notizblatt des Hessischen Landesamtes für Bodenforschung zu Wiesbaden, 103:103-186.

Topachevskiy, V., Nesin, V., and Topachevskiy, I. 1998. Biozonal microtheriological scheme (stratigraphic distribution of small mammals-Insectivora, Lagomorpha, Rodentia) of Neogene of the northern part of Eastern Paratethys. Vestnik zoologii, 32:76-87.

von Koenigswald, W. 1980. Schmelzstruktur und Morphologie in den Molaren der-Arvicolidae (Rodentia). Abhandlungen der Senckenbergischen Naturforschenden Gesellschaft, 539(1):1-129.

von Koenigswald, W. 1996. Die Zahl der Schmelzschichten in den Inzisiven bei den Lagomorpha und ihre systematische Bedeutung. Bonner Zoologische Beiträge, 46:33-57.

von Koenigswald, W., Anders, U., Engels, S., Schultz, J.A., and Ruf, I. 2010. Tooth morphology in fossil and extant Lagomorpha (Mammalia) reflects different mastication patterns. Journal of Mammalian Evolution, 17:275-299.

von Koenigswald, W., and Clemens, W. 1992. Levels of complexity in the microstructure of mammalian enamel and their application in studies of systematics. Scanning Microscopy, 6:195-217.

von Koenigswald, W. and Martin, L.D. 1984. Revision of the fossil and recent Lemminae (Rodentia, Mammalia). Papers in Vertebrate Paleontology Honoring Robert Warren Wilson. Carnegie Museum of Natural History Special Publication, 9:122-137.

von Koenigswald, W. and Sander, P. 1997. Glossary of terms used for enamel microstructures, p. 267-280. In Koenigswald, W. von and Sander, P. (eds.), Tooth Enamel Microstructure. Balkema, Rotterdam. 